Article

\title{
Delivery of Inoculum of Rhizophagus irregularis via Seed Coating in Combination with Pseudomonas libanensis for Cowpea Production
}

\author{
Ying Ma ${ }^{1, *(\mathbb{D})}$, Aleš Látr ${ }^{2}$, Inês Rocha ${ }^{1}$, Helena Freitas ${ }^{1}$, Miroslav Vosátka ${ }^{3,4}$ and \\ Rui S. Oliveira ${ }^{1,5}$ \\ 1 Centre for Functional Ecology-Science for People \& the Planet, Department of Life Sciences, \\ University of Coimbra, 3000-456 Coimbra, Portugal; ines.sousa.rocha@gmail.com (I.R.); \\ hfreitas@uc.pt (H.F.); rsoliveira@uc.pt (R.S.O.) \\ 2 Symbiom Ltd., 56301 Lanškroun, Czech Republic; latr@symbiom.cz \\ 3 Institute of Botany, Academy of Sciences of the Czech Republic, 25343 Prühonice, Czech Republic; \\ miroslav.vosatka@ibot.cas.cz \\ 4 Department of Experimental Plant Biology, Charles University, Faculty of Science, 12844 Prague, \\ Czech Republic \\ 5 Department of Environmental Health, Research Centre on Health and Environment, School of Allied Health \\ Sciences, Polytechnic Institute of Porto, 4200-072 Porto, Portugal \\ * Correspondence: cathymaying@gmail.com; Tel.: +351-239-240-752
}

Received: 21 November 2018; Accepted: 9 January 2019; Published: 15 January 2019

check for updates

\begin{abstract}
Cowpea (Vigna unguiculata L. Walp) is an important legume grown primarily in semi-arid area. Its production is generally inhibited by various abiotic and biotic stresses. The use of beneficial microorganisms (e.g., plant growth promoting bacteria (PGPB) and arbuscular mycorrhizal fungi $(\mathrm{AMF}))$ can enhance agricultural production, as these microorganisms can improve soil fertility and plant tolerance to environmental stresses, thus enhancing crop yield in an eco-friendly manner. Application of PGPB and AMF in large scale agriculture needs to be improved. Thus, the use of seed coating could be an efficient mechanism for placement of inocula into soils. The aim of this study was to evaluate the effects of the AMF Rhizophagus irregularis BEG140 and the PGPB Pseudomonas libanensis TR1 alone or in combination on the biomass and physiological traits of cowpea. Four treatments were set: (i) non-inoculated control; (ii) PGPB; (iii) AMF applied via seed coating; and (iv) PGPB + AMF applied via seed coating. Cowpea plants inoculated via seed coating with $R$. irregularis and those inoculated with $R$. irregularis $+P$. libanensis showed root mycorrhizal colonization of $21.7 \%$ and $24.2 \%$, respectively. PGPB P. libanensis was efficient in enhancing plant biomass and seed yield. There was no benefit of single (AMF) or dual (PGPB + AMF) inoculation on plant growth or seed yield. The application of beneficial soil microorganisms can be a viable approach for sustainable cowpea production in precision agriculture scenarios.
\end{abstract}

Keywords: seed coating; plant growth promoting bacteria; arbuscular mycorrhizal fungi; Vigna unguiculata; sustainable agriculture

\section{Introduction}

Abuse of agrochemicals in agriculture to meet the needs of a growing human population can deteriorate the overall ecosystem quality and compromise the environment and public health. Sustainable agriculture has focused on developing new practices including the use of beneficial microorganisms as a safe and eco-friendly tool for fostering food production without compromising ecosystems services. Beneficial microbes, such as arbuscular mycorrhizal fungi (AMF) and plant 
growth promoting bacteria (PGPB), representing a key functional interface between plant roots and soils, are considered as natural biofertilizers, due to their ability to exert direct and indirect beneficial effects on soil quality and structure, crop growth and quality, abiotic (e.g., drought, salt, metals and extreme temperature) and biotic (e.g., phytopathogens) stress resistance, and consequently agricultural sustainability [1-5].

Cowpea is a very important food source and a widely cultivated legume throughout the world, particularly in Asia, Africa, and Latin America. Cowpea makes great contribution to fulfilling human dietary protein requirements [6]. However, various abiotic and biotic stresses inhibit plant growth and grain yield $[7,8]$. Thus, the application of beneficial microbes in situ as an elicitor or stimulator could represent a good choice to enhance plant growth under normal or stressful conditions. Plant growth promoting substances produced by PGPB result in reduced use of chemical fertilizers, while the solubilized mineral nutrients (e.g., nitrogen, phosphorus and potassium) and phytohormones (e.g., indole-3-acetic acid and cytokinins) could be available for legume uptake [2,3]. Moreover, legumes are associated with AMF under a complex hyphal network, which improve plant growth and development, mainly through enhancing nutrient uptake [9]. To achieve maximum performance of beneficial inoculum, it is important that the introduced microbes compete effectively against the indigenous microbial community and present their functional traits. Root colonization by AMF is a prerequisite for the success of inoculum application, since it is a critical process in establishment of plant-microbe association [10].

It is noteworthy that the application of beneficial microbes has not yet been widely integrated in agriculture, because of its inadequate inocula delivery process and lack of awareness by farmers. Therefore, the development of a suitable delivery system of beneficial microbes that retains microbial functional activities is crucial for sustainable agriculture. Among common delivery methods, integration of symbiotic microorganisms (e.g., AMF and PGPB) in coating agents around the seed (so-called seed coating) offers great potential to enhance seed establishment and plant field performance in a cost-efficiency way [11,12]. Therefore, this study was conducted to examine the effects of AMF (inoculated via seed coating) and PGPB alone or in combination on the production of cowpea. The specific objectives of the study were: (1) to deliver AMF through seed coating; (2) to evaluate the effects of AMF and PGPB inoculation on the biomass and physiological traits of cowpea; and (3) to determine the colonization capacity of AMF when inoculated via seed coating.

\section{Materials and Methods}

\subsection{Experimental Plant}

An important indigenous grain legume, cowpea (Vigna unguiculata (L.) Walp. cv. Fradel) was selected for this study, as it has high-protein seeds and nutrient-rich edible leaves, which contribute to fulfilling the high nutritional requirements of humans. In addition, it may tolerate drought and heat, and can thus be grown successfully in many areas.

\subsection{Bacterial Strain}

The abiotic stress (drought, salt and heavy metals) resistant PGPB strain Pseudomonas libanensis TR1 (GenBank accession no. KR051238) originally isolated from the rhizosphere of Trifolium repens grown in serpentine soils in Bragança, northeast of Portugal, was obtained from the culture collection of the Centre for Functional Ecology, University of Coimbra [13]. P. libanensis TR1 was chosen in this study due to its beneficial biochemical characteristics, as shown in Table 1. P. libanensis TR1 exhibited tolerance to heat $\left(38^{\circ} \mathrm{C}\right)$, salinity $(8 \%)$ and severe drought $(-1.5 \mathrm{Mpa})$. It was able to fix $\mathrm{N}_{2}$, solubilize $\mathrm{P}$, as well as produce 1-aminocyclopropane-1-carboxylate (ACC) deaminase, siderophore, IAA and ammonia $\left(\mathrm{NH}_{3}\right)$. Overnight grown bacterial culture was centrifuged at $6000 \mathrm{rpm}$ for $10 \mathrm{~min}$ and the pellet was washed twice with biological saline $(0.85 \% \mathrm{KCl})$. The pellet was resuspended in 
biological saline and the optical density $(600 \mathrm{~nm})$ of bacterial suspension was adjusted to 1 (about $1 \times 10^{9}$ colony-forming units per $\mathrm{mL}$ ).

Table 1. Biochemical characteristics of Pseudomonas libanensis TR1.

\begin{tabular}{|c|c|c|c|}
\hline Characteristic & Parameter & Unit & P. libanensis TR1 \\
\hline \multirow{3}{*}{ Abiotic stress resistance } & Salt tolerance & $\%$ & 8 \\
\hline & Osmotic tolerance * & $\mathrm{ng}$ & + \\
\hline & Temperature tolerance & ${ }^{\circ} \mathrm{C}$ & $4-38$ \\
\hline \multirow{6}{*}{$\begin{array}{l}\text { Plant growth } \\
\text { promoting traits }\end{array}$} & $\begin{array}{l}\text { ACC deaminase } \\
\text { production }\end{array}$ & $\begin{array}{c}\mu \mathrm{m} \alpha-\mathrm{KB} \mathrm{mg} \mathrm{m}^{-1} \mathrm{~h}^{-1} \\
\text { protein }\end{array}$ & $34.2 \pm 6.7$ \\
\hline & P solubilization & nq & + \\
\hline & IAA production & $\mathrm{mg} \mathrm{L}^{-1}$ & $88.2 \pm 5.6$ \\
\hline & Siderophore & CAS: mm & $1.0 \pm 0.1$ \\
\hline & $\mathrm{N}_{2}$ fixation & nq & + \\
\hline & $\mathrm{NH}_{3}$ production & nq & + \\
\hline
\end{tabular}

\subsection{Arbuscular Mycorrhizal Fungal Inoculum and Seed Coating}

The AMF isolate Rhizophagus irregularis BEG140 provided by Symbiom Ltd., Lanškroun, Czech Republic was multiplied with host plant Zea mays L. in a multi-spore pot culture containing a mixture of zeolite and expanded clay $(1: 1 ; v: v)$ for six months. The inoculum was sieved through a $250 \mu \mathrm{m}$ mesh and mixed with the coating material silicon dioxide and starch $(1: 1: 1 w / w)$. The most probable number (MPN) [14] value of the inoculum was ca. 400,000 infective propagules (IPs) per kg. Cowpea seeds were surface-sterilized with $0.5 \%(v / v)$ sodium hypochlorite for $10 \mathrm{~min}$. After misting with sterile distilled water, seeds were coated by gradually adding inoculum-coating material mixture according to the pan coating method $[5,15]$ and then air dried at $25^{\circ} \mathrm{C}$ for $24 \mathrm{~h}$. This resulted in ca. 9 IP per plant and a buildup of $50 \%$ of seed weight.

\subsection{Microcosm Experiments}

For a pot experiment, a sterile substrate mixture composed of sand/loam soil:sand $(2: 1 ; v / v)$ was used. Substrate sterilization was done by autoclaving (twice at $121^{\circ} \mathrm{C}$ for $1 \mathrm{~h}$, with $24 \mathrm{~h}$ delay between the subsequent cycle). Main characteristics of the substrate were $94.3 \%$ of dry matter, $945 \mathrm{mg} \cdot \mathrm{kg}^{-1}$ of $\mathrm{K}, 48 \mathrm{mg} \cdot \mathrm{kg}^{-1}$ of $\mathrm{P}, 307 \mathrm{mg} \cdot \mathrm{kg}^{-1}$ of $\mathrm{N}, 4.8 \mathrm{mg} \cdot \mathrm{kg}^{-1}$ of $\mathrm{S}, 37 \mathrm{mg} \cdot \mathrm{kg}^{-1}$ of $\mathrm{Mg}, 870 \mathrm{mg} \cdot \mathrm{kg}^{-1}$ of Ca, and $\mathrm{pH} 7.2$.

Pots (height $20 \mathrm{~cm}$, diameter $16 \mathrm{~cm}$, volume $3 \mathrm{~L}$ ) containing $1 \mathrm{~kg}$ of substrate that were arranged on a greenhouse bench in a randomized block design included four treatments: (i) non-inoculated control; (ii) PGPB; (iii) AMF inoculated via seed coating; and (iv) PGPB + AMF inoculated via seed coating. Each treatment was replicated six times (six pots), each pot contained 2 seedlings. Pots of the control and PGPB treatments received two cowpea seeds coated using the same procedure described above except without AMF inoculum. Additionally, pots from the bacterial treatments received $1 \mathrm{~mL}$ of the bacterial suspension described above. Non-bacterial treatments received $1 \mathrm{~mL}$ of biological saline. Since our study focused on determining host-microbe compatibility and possible growth response, the bacterium was not introduced via seed coating. Pseudomonas libanesis showed low shelf life when coated on seed surface (personal communication); therefore, the bacterial suspension was applied directly into the seed vicinity. Pots of AMF coating treatments received two cowpea seeds coated with R. irregularis BEG140. Plants were grown in a greenhouse under 16/8 day/night regime for 10 weeks. Temperature and soil water content ranges were $25-30{ }^{\circ} \mathrm{C}$ and $55 \%-70 \%$, respectively. Pots of different treatments were rotated weekly to different bench positions throughout the greenhouse to minimize positional effects. 


\subsubsection{Plant Biomass}

At harvest, plants were carefully washed free of adhering substrate and separated from above-ground biomass (shoots and pods), and then fresh weight of shoots, roots and pods was measured. The number of seeds per pod and seed weight per pod was also recorded. The corresponding dry weight was subsequently determined following oven drying to a constant weight at $85{ }^{\circ} \mathrm{C}$. The shoot to root dry weight ratio, which reflects overall shoot to root balance, was calculated. Aliquots $(2 \mathrm{~g})$ of fresh leaves were separated and frozen in liquid nitrogen for determination of pigment content. Roots of all treatments were sampled to determine AMF colonization.

\subsubsection{Pigment Estimation}

Chlorophyll contents in cowpea leaves were determined by the $\mathrm{N}, \mathrm{N}$-Dimethylformamide (DMF) method [16]. Leaves $(0.5 \mathrm{~g})$ were homogenized in chilled DMF and stored at $4{ }^{\circ} \mathrm{C}$ in darkness for $16 \mathrm{~h}$. Photosynthetic pigments (chlorophyll $\mathrm{a}$, chlorophyll $\mathrm{b}$ and chlorophyll $\mathrm{a}+\mathrm{b}$ ) were estimated spectrophotometrically and calculated using the equations of Lichtenthaler and Wellburn [17].

\subsubsection{Mycorrhizal Colonization}

Root samples were cut into segments and stained with 0.05\% trypan blue in lactoglycerol [18]. Colonization was expressed as percent root length colonized (RLC) by AMF and estimated according to the grid-line intersect method [19] using an ocular grid at 100× magnification.

\subsubsection{Bacterial Analysis}

At harvest, $1 \mathrm{~g}$ of roots and rhizosphere soil was gently collected in $2 \mathrm{~mL}$ microtubes. Tubes were maintained at $4{ }^{\circ} \mathrm{C}$ and immediately transported to the laboratory for further processing. Once in the laboratory, tubes were frozen $\left(-20^{\circ} \mathrm{C}\right)$ until molecular analyses were carried out. Individually, an aliquot of approximately $0.15-0.2 \mathrm{~g}$ was used for DNA extraction using the NucleoSpin ${ }^{\circledR}$ soil extraction kit (Macherey-Nagel), and the obtained DNA was stored at $-20{ }^{\circ} \mathrm{C}$. Specific primers targeted at Pseudomonas 16S rRNA gene Ps-for (forward primer, $5^{\prime}$ GGTCTGAGAGGATGATCAGT 3') and Ps-rev (reverse primer, $5^{\prime}$ TTAGCTCCACCTCGCGGC $3^{\prime}$ ) were used to amplify a specific region (V2 to V8 variable region) of the gene [20]. Amplification was carried out following the conditions described in Rajwar and Sahgal [21], with slight modifications. Reaction mix contained $2.5 \mu \mathrm{M}$ of each primer, $12.5 \mu \mathrm{L}$ of DSF Taq Master Mix (BIORON) $(2.5 \mu \mathrm{L}$ of buffer, $200 \mu \mathrm{M}$ of dNTPs, $0.5 \mathrm{U}$ of DFS-Taq polymerase), and $1 \mu \mathrm{L}$ of template DNA in a final volume of $25 \mu \mathrm{L}$. Amplification was carried out in a $\mathrm{T} 100^{\mathrm{TM}}$ Thermal Cycler (BIO-RAD) and PCR conditions were as follows: an initial denaturation step of 5 min at $95^{\circ} \mathrm{C}$, followed by 35 cycles of $1 \mathrm{~min}$ at $94^{\circ} \mathrm{C}, 1 \mathrm{~min}$ at $57^{\circ} \mathrm{C}$, and $1 \mathrm{~min}$ at $72{ }^{\circ} \mathrm{C}$, with a final extension step of $10 \mathrm{~min}$ at $72{ }^{\circ} \mathrm{C}$. Five microliters of the obtained PCR products were analyzed using agarose (1\%) gel electrophoresis stained with GreenSafe Premium (NZYTech), to verify the presence of the Pseudomonas amplicon (990-bp product). After electrophoresis, amplified DNA was visualized using GelDoc ${ }^{\mathrm{TM}} \mathrm{XR}+$ system with the Image Lab software (2.0.1) (BIO-RAD).

\subsection{Statistical Analysis}

The treatment means were compared using one-way ANOVA followed by Tukey's Honestly Significant Difference (HSD) test $(p<0.05)$. All statistical analyses were carried out using SPSS 17.0.

\section{Results}

\subsection{AMF Colonization}

The AMF and cowpea formed a symbiotic relationship. $R$. irregularis was able to colonize the roots of cowpea. Inoculation with $R$. irregularis via seed coating resulted in $21.7 \%$ and $24.2 \%$ RLC in 
plants without and with PGPB, respectively (Figure 1). In addition, no AMF colonization was detected in the roots of non-mycorrhizal plants, indicating that there was no fungal cross-contamination among pots of different treatments.

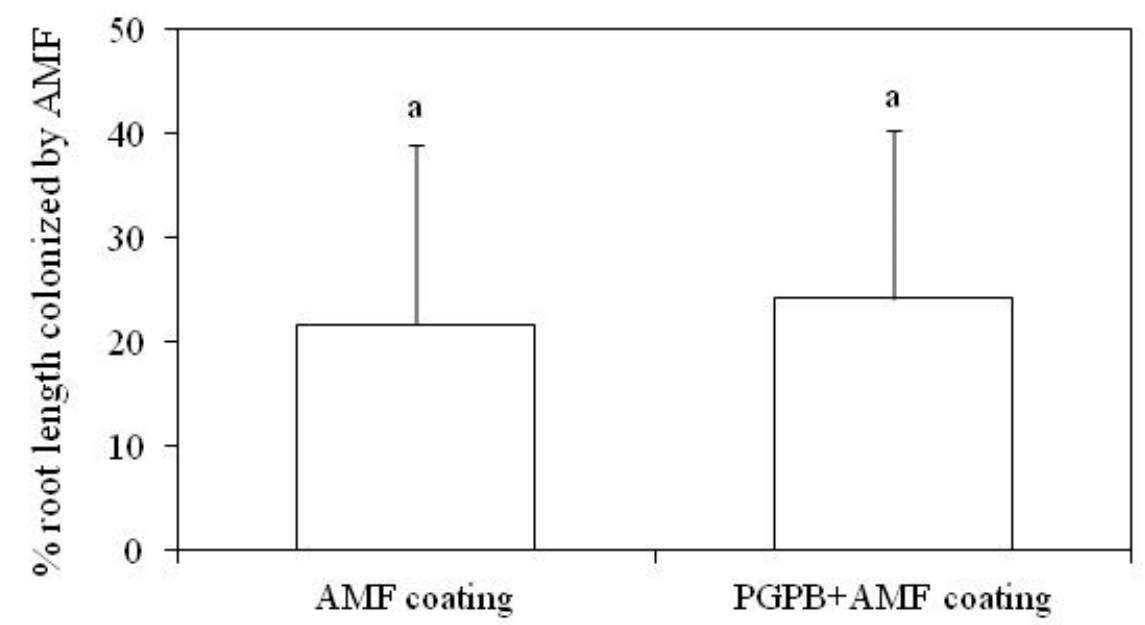

Figure 1. Percentage root length colonized (\%RLC) in the roots of cowpea via seed coating. AMF, arbuscular mycorrhizal fungi; PGPB, plant growth promoting bacteria. Error bars represent standard deviation. Data of columns indexed by the same letter are not significantly different according to Tukey's Honestly Significant Difference (HSD) test $(p<0.05)$.

\subsection{Bacterial Colonization}

P. libanensis TR1 was not detected by PCR in the roots and rhizosphere of cowpea plants inoculated with this PGPB strain. Thus, the presence of P. libanensis TR1 in our microcosms could not be confirmed after 10 weeks of plant growth.

\subsection{Plant Biomass and Chlorophyll Contents}

Plants from all treatments had a germination rate of $100 \%$. In our study, the pot experiment was performed under non-stress conditions, which ensured favorable growing conditions. Data indicate that inoculation with AMF R. irregularis via seed coating did not affect plant growth (e.g., shoot and root dry weight) (Figure 2). The same trend was observed for plant fresh weight. Notably, $P$. libanensis significantly $(p<0.05)$ increased shoot and total plant dry weight, as well as shoot to root dry weight ratio by $111 \%, 101 \%$ and $83 \%$, respectively, compared to the control treatment. This shows that inoculation of cowpea with PGPB P. libanensis was more effective in enhancing plant growth. Nevertheless, dual inoculation with AMF and PGPB inocula resulted in no pronounced changes in plant growth performance in comparison with the control treatment.

Table 2 provides the leaf photosynthetic pigment contents of cowpea. Application of AMF or PGPB alone or in combination did not significantly influence cowpea leaf chlorophyll $a$, chlorophyll $b$, chlorophyll $\mathrm{a}+\mathrm{b}$, and chlorophyll $\mathrm{a} / \mathrm{b}$ ratio, compared to the control treatment.

Table 2. Chlorophyll contents in leaves of cowpea.

\begin{tabular}{|c|c|c|c|c|}
\hline Treatment & Chlorophyll a (mg g $\left.{ }^{-1}\right)$ & Chlorophyll b (mg g ${ }^{-1}$ ) & Chlorophyll a + b $\left(\mathrm{mg} \mathrm{g}^{-1}\right)$ & Chlorophyll a/b Ratio \\
\hline Control & $1.89 \pm 0.43 a$ & $3.04 \pm 0.70 a$ & $4.99 \pm 1.12 \mathrm{a}$ & $0.63 \pm 0.06 a$ \\
\hline PGPB & $2.24 \pm 0.22 \mathrm{a}$ & $3.50 \pm 0.41 \mathrm{a}$ & $5.80 \pm 0.64 \mathrm{a}$ & $0.64 \pm 0.02 a$ \\
\hline AMF coating & $2.21 \pm 0.43 \mathrm{a}$ & $3.38 \pm 0.54 \mathrm{a}$ & $5.65 \pm 0.95 \mathrm{a}$ & $0.65 \pm 0.04 \mathrm{a}$ \\
\hline PGPB + AMF coating & $2.33 \pm 0.38 \mathrm{a}$ & $3.53 \pm 0.49 a$ & $5.93 \pm 0.88 \mathrm{a}$ & $0.66 \pm 0.03 \mathrm{a}$ \\
\hline
\end{tabular}

PGPB, plant growth promoting bacteria; AMF, arbuscular mycorrhizal fungi. Values are means \pm standard deviation. Data of columns indexed by the same letter are not significantly different according to Tukey's Honestly Significant Difference (HSD) test $(p<0.05)$. 
a

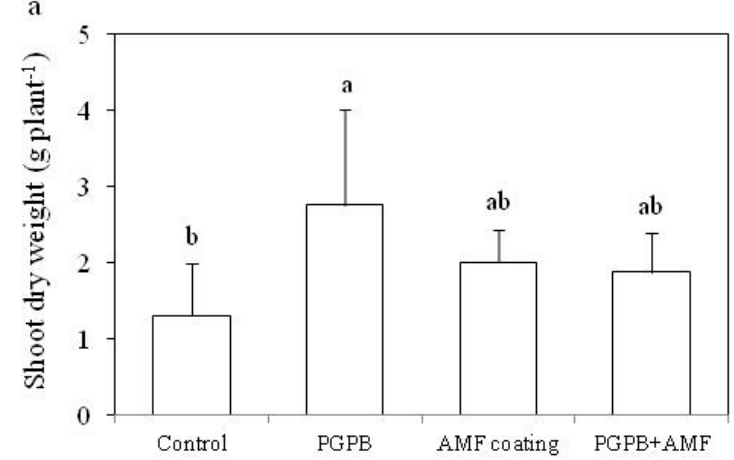

b

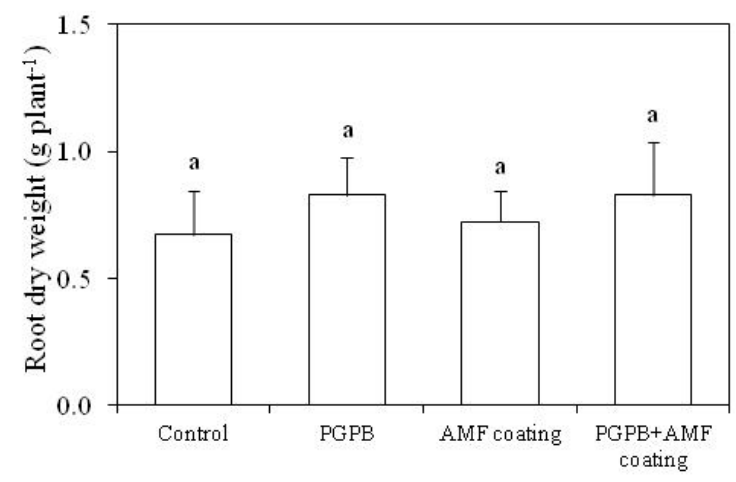

c

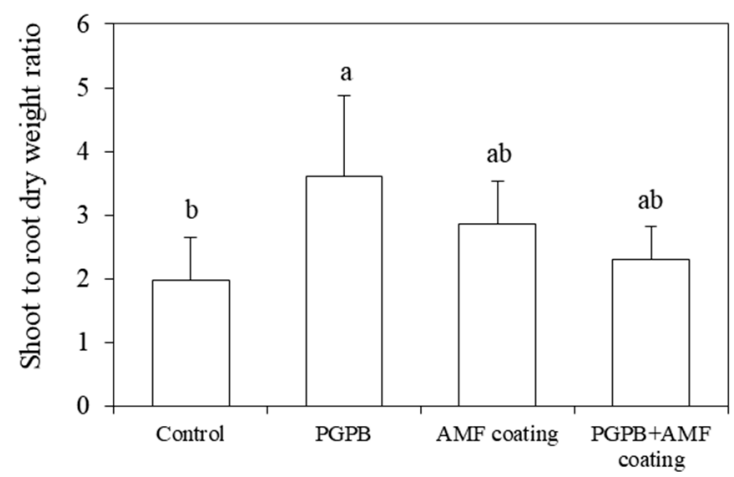

Figure 2. Effects of individual and combined inoculation of PGPB and AMF on shoot (a) and root (b) dry weight, and shoot to root dry weight ratio (c). Error bars represent standard deviation. Data of columns indexed by the same letter are not significantly different according to Tukey's Honestly Significant Difference (HSD) test $(p<0.05)$.

\subsection{Effects of Microbes on Seed Yield}

The effects of inoculation with $R$. irregularis or P. libanensis, alone or in combination on seed production of cowpea were demonstrated in terms of number of pods and seeds, seed weight and seed yield per plant compared with the control (Table 3). AMF inoculation did not $(p>0.05)$ affect seed yield of cowpea, but PGPB inoculation significantly improved the seed yield by $52 \%$ when compared to the control treatment. However, co-inoculation with AMF and PGPB resulted in no changes in cowpea seed yield. 
Table 3. Number of pods and seeds, seed weight and seed yield of cowpea.

\begin{tabular}{ccccc}
\hline \multirow{2}{*}{ Treatment } & Pod Number & Seed Number & Seed Weight & * Seed Yield \\
\cline { 2 - 5 } & Per Plant & Per Pod & Per Seed (g) & Per Plant (g) \\
\hline Control & $2.3 \pm 0.5 \mathrm{a}$ & $3.6 \pm 0.7 \mathrm{a}$ & $0.18 \pm 0.0 \mathrm{a}$ & $1.43 \pm 0.3 \mathrm{~b}$ \\
PGPB & $2.6 \pm 1.1 \mathrm{a}$ & $3.5 \pm 0.9 \mathrm{a}$ & $0.22 \pm 0.0 \mathrm{a}$ & $2.18 \pm 0.4 \mathrm{a}$ \\
AMF coating & $2.3 \pm 0.5 \mathrm{a}$ & $2.5 \pm 1.5 \mathrm{a}$ & $0.18 \pm 0.1 \mathrm{a}$ & $1.23 \pm 0.3 \mathrm{~b}$ \\
PGPB + AMF coating & $2.4 \pm 0.9 \mathrm{a}$ & $3.7 \pm 1.8 \mathrm{a}$ & $0.17 \pm 0.1 \mathrm{a}$ & $1.19 \pm 0.5 \mathrm{~b}$ \\
\hline
\end{tabular}

Values are means \pm standard deviation. Data of columns indexed by the same letter are not significantly different according to Tukey's Honestly Significant Difference (HSD) test $(p<0.05) .{ }^{*}$ Seed yield of a legume plant $=$ number of pods per plant $\times$ number of seeds per pod $\times$ mean seed weight [22].

\section{Discussion}

The success of seed coating largely depends on an accurate selection of the coating material, which may influence seed germination [12,23]. In our study, seeds from both non-coated and coated treatments exhibited a germination rate of $100 \%$, showing that the process of seed coating using a mixture of AMF inoculum and silicon dioxide did not reduce the germination. This finding is in accordance with the results of Oliveira et al. [5] on Triticum aestivum.

Results of our research revealed successful colonization and survival of AMF R. irregularis via seed coating in plants with and without PGPB (Figure 1). Recently, Omirou et al. [24] reported that, in sterilized soils, cowpea inoculated with AMF (a mixed inoculum of Rhizophagus intraradices and Funneliformis mosseae) and co-inoculated with AMF and a nitrogen-fixing bacterium Bradyrhizobium sp. exhibited similar colonization percentages of about $23 \%$ and $21 \%$, respectively. The addition of PGPB did not influence the percent RCL compared to AMF-coating treatments without PGPB. Dissimilarly, Krishnamoorthy et al. [25] showed that co-inoculation treatment with the AMF Rhizophagus intraradices and bacterium Massilia sp. resulted in higher AMF root colonization compared to the $R$. intraradices single inoculation treatment. It is well known that several factors, such as soil structure, organic fertilization, and beneficial bacterial communities, contribute significantly to spore germination, development of fungal mycelia and AMF colonization rate [26-28]. For instance, PGPB may produce metabolites or create a niche that increase spore germination rate and stimulate AMF mycelia in the rhizosphere. The production of plant hormones by PGPB has been suggested as mediating these processes [28]. The enhanced AMF colonization by Massilia sp. is probably attributed to the plant growth promoting traits of the bacterial strain and an existing cross talk between the signaling pathways leading to bacterial and mycorrhizal colonization [29]. Our finding displays that application of PGPB was not favorable to the development of R. irregularis associated with cowpea. Future research is needed to focus on functional compatibility relationships between AMF and PGPB.

It has been well demonstrated that AMF can alleviate environmental stresses (e.g., drought, salinity and heavy metals) and increase seedling survival rate, growth and development of various plants such as Allium cepa, Calendula officinalis, Cicer arietinum, Poncirus trifoliata, Sesbania sesban and Vigna unguiculata due to their effects on nutrient dynamics and water acquisition [30-36]. However, no significant differences were noted in biomass yield between mycorrhizal and non-mycorrhizal plants (Figure 2). As reported by Muthukumar and Udaiyan [37], soil conditions that favor plant growth can also facilitate the establishment of mycorrhizal association, since they increase the chances for plant roots to encounter AMF. In our study, although well-grown plants (Figure 2) along with successful AMF colonization (Figure 1) were obtained, there were no significant effects of AMF on plant growth. AMF might not benefit plants when net cost of the symbiosis is equal or exceeds net benefit [38]. The absence of growth promotion by $R$. irregularis could also be attributed to the limitations of space for the growth of cowpea in the pots. Thus, the full potential of AMF inocula should be assessed in future studies under field conditions.

The presence of $P$. libanensis TR1 in the roots and rhizosphere of cowpea plants was not detected by PCR. Inoculated PGPB might initially colonize the roots and rhizosphere of target plants at high levels, but these can decline in a few weeks [39]. Despite the decreasing concentration of inoculated 
PGPB, their beneficial effect on plant performance can be observed throughout the whole cycle of the target plant [40]. Although our inoculated P. libanensis TR1 strain was not detected in the roots and rhizosphere of cowpea after 10 weeks of plant growth, we cannot exclude the positive contribution of inoculated PGPB to the growth and yield of cowpea (Figure 2 and Table 3). PGPB inoculation has been considered as an effective alternative bio-technique to improve plant resistance to environmental stress, quality and yield besides the conventional plant breeding and genetic engineering, which are time consuming and costly [41]. PGPB P. libanensis had great potential as a bioinoculant to enhance cowpea growth (e.g., shoot and total plant dry weight). The significant increase in the shoot to root dry weight ratio of PGPB inoculated plants (Figure 2) implies that $P$. libanensis TR1 might also participate in the partitioning of carbon sources and minerals within the plant (shoot-specific activity). The results obtained herein are in agreement with Bashan and Dubrovsky [42]. Moreover, the highest root dry weight, although not significant, was obtained with the treatment of PGPB (Figure 2). It is interesting to note that, in dual inoculation with AMF and PGPB, $R$. irregularis compromised the stimulatory effects of PGPB. This was probably because $R$. irregularis exerted a negative or neutral effect on plant growth within the plant-mycorrhiza-soil system. Similarly, Nouri et al. [43] argued that the negative or neutral growth impact can be attributed to the fact that AMF confer a benefit (e.g., a qualitative benefit) other than growth promotion, or the benefit is not evident under the respective experimental conditions. During symbiotic performance, the role of PGPB on AMF-plant association remains unclear.

The leaf chlorophyll content as an indicator parameter of plant health was determined in all treatments (Table 2). Our findings indicate that, under non-stress conditions, application of PGPB enhanced plant growth performance of cowpea. We assume that PGPB inoculation did not affect chloroplast development in plants; therefore, chlorophyll production maintained no change between non-inoculated and inoculated treatments.

Seed yield has been regarded as an important measure of sustainable crop production. Even though a large range of seed yield has been recorded for cowpea, the production is usually low, due to the soil erosion and low fertility [44]. Our finding displayed that single PGPB inoculation considerably enhanced cowpea seed yield, whereas dual inoculation with AMF and PGPB had no effects (Table 3). Similarly, Valverde et al. [45] found the co-inoculation of phosphate-solubilizing Pseudomonas jessenii and $\mathrm{N}_{2}$-fixing Mesorhizobium ciceri strains results in the highest increase in seed yield of Cicer arietinum. The positive effects are probably due to a bio-fertilization effect of PGPB [46].

\section{Conclusions}

The inoculum of AMF applied via seed coating alone or in combination with PGPB successfully colonized the roots of cowpea, demonstrating the success of seed coating as an effective AMF inoculum delivery system. PGPB inoculation significantly enhanced shoot dry weight and total biomass production as well as seed yield of cowpea, which may be attributed to the observed beneficial traits of PGPB P. libanensis. The application of beneficial microbes should be encouraged in cowpea growing areas. Our findings indicate that application of AMF via seed coating can serve as an innovative and promising approach for sustainable field-based plant cultivation, as it has the advantage of reducing the amount of inoculum needed. Nevertheless, field scale studies will be essential to validate these finding under real agricultural scenarios.

Author Contributions: Methodology, Y.M. and R.S.O.; Validation, Y.M., A.L. and I.R.; Formal Analysis, Y.M. and A.L.; Investigation, A.L.; Resources, Y.M. and M.V.; Writing-Original Draft Preparation, Y.M.; Writing-Review and Editing, Y.M. and R.S.O.; Supervision, H.F.; and Funding Acquisition, R.S.O.

Funding: This work was financed by Portuguese national funds through Programa Operacional Competitividade e Internacionalização (POCI), Project 3599-Promover a Produção Científica e Desenvolvimento Tecnológico e a Constituição de Redes Temáticas (3599-PPCDT) and Fundo Europeu de Desenvolvimento Regional (FEDER) under Project POCI-01-0145-FEDER-016801 and by FCT under Projects PTDC/AGR-TEC/1140/2014. A. Látr thanks Eurostars project E!8275.

Acknowledgments: Y.M., I.R. and R.S.O. acknowledge the support of Fundação para a Ciência e a Tecnologia (FCT) through research grants SFRH/BPD/76028/2011, SFRH/BD/100484/2014 and SFRH/BPD/85008/2012, 
Fundo Social Europeu (FSE) and Programa Operacional do Capital Humano (POCH). This work is financed by National Funds through the FCT within the project UID/BIA/04004/2013. A.L. acknowledges the funding of Eurostars project E! 8275 MicroCoat. The authors wish to thank Pablo Souza-Alonso whose comments improved the manuscript.

Conflicts of Interest: The authors declare no conflict of interest.

\section{References}

1. Fitter, A.H.; Helgason, T.; Hodge, A. Nutritional exchanges in the arbuscular mycorrhizal symbiosis: Implications for sustainable agriculture. Fungal Biol. Rev. 2011, 25, 68-72. [CrossRef]

2. Ma, Y.; Prasad, M.N.V.; Rajkumar, M.; Freitas, H. Plant growth promoting rhizobacteria and endophytes accelerate phytoremediation of metalliferous soils. Biotechnol. Adv. 2011, 29, 248-258. [CrossRef] [PubMed]

3. Ma, Y.; Oliveira, R.S.; Freitas, H.; Zhang, C. Biochemical and molecular mechanisms of plant-microbe-metal interactions: Relevance for phytoremediation. Front. Plant Sci. 2016, 7, 918. [CrossRef] [PubMed]

4. Oliveira, R.S.; Ma, Y.; Rocha, I.; Carvalho, M.F.; Vosátka, M.; Freitas, H. Arbuscular mycorrhizal fungi are an alternative to the application of chemical fertilizer in the production of the medicinal and aromatic plant Coriandrum sativum L. J. Toxicol. Environ. Health A 2016, 79, 320-328. [CrossRef] [PubMed]

5. Oliveira, R.S.; Rocha, I.; Ma, Y.; Vosátka, M.; Freitas, H. Seed coating with arbuscular mycorrhizal fungi as an ecotechnological approach for sustainable agricultural production of common wheat (Triticum aestivum L.). J. Toxicol. Environ. Health A 2016, 79, 329-337. [CrossRef]

6. Gonçalves, A.; Goufo, P.; Barros, A.; Domínguez-Perles, R.; Trindade, H.; Rosa, E.A.; Ferreira, L.; Rodrigues, M. Cowpea (Vigna unguiculata L. Walp), a renewed multipurpose crop for a more sustainable agri-food system: Nutritional advantages and constraints. J. Sci. Food Agric. 2016, 96, 2941-2951. [CrossRef]

7. Farooq, M.; Hussain, M.; Wahid, A.; Siddique, K.H.M. Drought stress in plants: An overview. In Plant Responses to Drought Stress; Aroca, R., Ed.; Springer Press: Berlin/Heidelberg, Germany, 2012; pp. 1-33.

8. Kareem, K.T.; Taiwo, M.A. Interactions of viruses in cowpea: Effects on growth and yield parameters. Virol. J. 2007, 4, 1-15. [CrossRef]

9. Van Der Heijden, M.G.; Streitwolf-Engel, R.; Riedl, R.; Siegrist, S.; Neudecker, A.; Ineichen, K.; Boller, T.; Wiemken, A.; Sanders, I.R. The mycorrhizal contribution to plant productivity, plant nutrition and soil structure in experimental grassland. New Phytol. 2006, 172, 739-752. [CrossRef]

10. Reinhold-Hurek, B.; Hurek, T. Living inside plants: Bacterial endophytes. Curr. Opin. Plant Biol. 2011, 14, 435-443. [CrossRef]

11. Ehsanfar, S.; Mdarre, S. Crop protection by seed coating. Commun. Agric. Appl. Biol. Sci. 2005, 70, $225-229$.

12. Pedrini, S.; Merritt, D.J.; Stevens, J.; Dixon, K. Seed coating: Science or marketing spin? Trends Plant Sci. 2017, 22, 106-116. [CrossRef]

13. Ma, Y.; Rajkumar, M.; Zhang, C.; Freitas, H. Inoculation of Brassica oxyrrhina with plant growth promoting bacteria for the improvement of heavy metal phytoremediation under drought conditions. J. Hazard. Mater. 2016, 320, 36-44. [CrossRef] [PubMed]

14. Porter, W. The "most probable number" method for enumerating infective propagules of vesicular arbuscular mycorrhizal fungi in soil. Aust. J. Soil Res. 1979, 17, 515-519. [CrossRef]

15. Scott, J.M.; Hill, C.B.; Jessop, R.S. Growth chamber study of phosphorus applied as drilled granules or as seed coatings to wheat sown in soils differing in P-sorption capacity. Fertil. Res. 1991, 29, 281-287. [CrossRef]

16. Moran, R. Formulae for determination of chlorophyllous pigments extracted with $N, N$-Dimethylformamide. Plant Physiol. 1982, 69, 1376-1381. [CrossRef] [PubMed]

17. Lichtenthaler, H.; Wellburn, A. Determination of total carotenoids and chlorophylls a and b of leaf extracts in different solvents. Biochem. Soc. Trans. 1983, 603, 591-592. [CrossRef]

18. Koske, R.E.; Gemma, J.N. A modified procedure for staining roots to detect VA mycorrhizas. Mycol. Res. 1989, 92, 486-505. [CrossRef]

19. Mcgonigle, T.P.; Miller, M.H.; Evans, D.G.; Fairchild, G.L.; Swan, J.A. A new method which gives an objective measure of colonization of roots by vesicular-arbuscular mycorrhizal fungi. New Phytol. 1990, 155, 495-501. [CrossRef] 
20. Widmer, F.; Seidler, R.J.; Gillevet, P.M.; Watrud, L.S.; Di Giovanni, G.D. A highly selective PCR protocol for detecting $16 \mathrm{~S}$ rRNA genes of the genus Pseudomonas (sensu stricto) in environmental samples. Appl. Environ. Microbiol. 1998, 64, 2545-2553.

21. Rajwar, A.; Sahgal, M. Phylogenetic relationships of Fluorescent pseudomonads deduced from the sequence analysis of 16S rRNA, Pseudomonas-specific and rpoD genes. 3 Biotech 2016, 6, 80. [CrossRef]

22. Sinha, S.K. Yield, yield components and plant ideotype in food legumes. In: Food legume crops: Improvement and production. FAO Plant Prod. Protect. Ser. 1977, 9, 123-131.

23. Yang, D.; Wang, N.; Yan, X.; Shi, J.; Zhang, M.; Wang, Z.; Yuan, H. Microencapsulation of seed-coating tebuconazole and its effects on physiology and biochemistry of maize seedlings. Colloids Surf. B Biointerfaces 2014, 114, 241-246. [CrossRef] [PubMed]

24. Omirou, M.; Fasoula, D.A.; Ioannides, I.M. Bradyrhizobium inoculation alters indigenous AMF community assemblages and interacts positively with AMF inoculum to improve cowpea performance. Appl. Soil Ecol. 2016, 108, 381-389. [CrossRef]

25. Krishnamoorthy, R.; Kim, K.; Subramanian, P.; Senthilkumar, M.; Anandham, R.; Sa, T. Arbuscular mycorrhizal fungi and associated bacteria isolated from salt-affected soil enhances the tolerance of maize to salinity in coastal reclamation soil. Agric. Ecosyst. Environ. 2016, 231, 233-239. [CrossRef]

26. Crecchio, C.; Curci, M.; Mininni, R.; Ricciuti, P.; Ruggiero, P. Short-term effects of municipal solid waste compost amendments on soil carbon and nitrogen content, some enzyme activities and genetic diversity. Biol. Fertil. Soils 2001, 34, 311-318. [CrossRef]

27. Johansson, J.; Paul, L.R.; Finlay, R.D. Microbial interactions in the mycorrhizosphere and their significance for sustainable agriculture. FEMS Microbiol. Ecol. 2004, 48, 1-13. [CrossRef]

28. Gryndler, M.; Hrselová, H.; Sudová, R.; Gryndlerová, H.; Rezácová, V.; Merhautová, V. Hyphal growth and mycorrhiza formation by the arbuscular fungus Glomus calaroideum BEG 23 is stimulated by humic substances. Mycorrhiza 2005, 15, 483-488. [CrossRef]

29. Genre, A.; Russo, G. Does a common pathway transduce symbiotic signals in plant-microbe interactions? Front. Plant Sci. 2016, 7, 96. [CrossRef]

30. Bolandnazar, S.; Aliasgarzad, N.; Neishabury, M.R.; Chaparzadeh, N. Mycorrhizal colonization improves onion (Allium cepa L.) yield and water use efficiency under water deficit condition. Sci. Hortic. 2007, 114, 11-15. [CrossRef]

31. Pellegrino, E.; Bedini, S. Enhancing ecosystem services in sustainable agriculture: Biofertilization and biofortification of chickpea (Cicer arietinum L.) by arbuscular mycorrhizal fungi. Soil Biol. Biochem. 2014, 68, 429-439. [CrossRef]

32. Allah, E.F.A.; Hashem, A.; Alqarawi, A.A.; Bahkali, A.H.; Alwhibi, M.S. Enhancing growth performance and systemic acquired resistance of medicinal plant Sesbania sesban (L.) Merr using arbuscular mycorrhizal fungi under salt stress. Saudi J. Biol. Sci. 2015, 22, 274-283.

33. Li, J.F.; He, X.H.; Li, H.; Zheng, W.J.; Liu, J.F.; Wang, M.Y. Arbuscular mycorrhizal fungi increase growth and phenolics synthesis in Poncirus trifoliate under iron deficiency. Sci. Hortic. 2015, 183, 87-92. [CrossRef]

34. Hristozkova, M.; Geneva, M.; Stancheva, I.; Boychinova, M.; Djonova, E. Contribution of arbuscular mycorrhizal fungi in attenuation of heavy metal impact on Calendula officinalis development. Appl. Soil Ecol. 2016, 101, 57-63. [CrossRef]

35. Oliveira, R.S.; Carvalho, P.; Marques, G.; Ferreira, L.; Nunes, M.; Rocha, I.; Ma, Y.; Carvalho, M.F.; Vosátka, M.; Freitas, H. Increased protein content of chickpea (Cicer arietinum L.) inoculated with arbuscular mycorrhizal fungi and nitrogen-fixing bacteria under water deficit conditions. J. Sci. Food Agric. 2017, 97, 4379-4385. [CrossRef] [PubMed]

36. Oliveira, R.S.; Carvalho, P.; Marques, G.; Ferreira, L.; Pereira, S.; Nunes, M.; Rocha, I.; Ma, Y.; Carvalho, M.F.; Vosátka, M.; et al. Improved grain yield of cowpea (Vigna unguiculata) under water deficit after inoculation with Bradyrhizobium elkanii and Rhizophagus irregularis. Crop Pasture Sci. 2017, 68, 1052-1059. [CrossRef]

37. Muthukumar, T.; Udaiyan, K. Arbuscular mycorrhizas in cycads of southern India. Mycorrhiza 2002, 12, 213-217. [PubMed]

38. Johnson, N.C.; Graham, J.H.; Smith, F.A. Functioning of mycorrhizal associations along the mutualism-parasitism continuum. New Phytol. 1997, 135, 575-585. [CrossRef]

39. Haas, D.; Défago, G. Biological control of soil-borne pathogens by Fluorescent pseudomonads. Nat. Rev. Microbiol. 2005, 3, 307-331. [CrossRef] 
40. Rosas, S.B.; Avanzini, G.; Carlier, E.; Pasluosta, C.; Pastor, N.; Rovera, M. Root colonization and growth promotion of wheat and maize by Pseudomonas aurantiaca SR1. Soil Biol. Biochem. 2009, 41, 1802-1806. [CrossRef]

41. Barrow, J.R.; Lucero, M.E.; Reyes-Vera, I.; Havstad, K.M. Do symbiotic microbes have a role in plant evolution, performance and response to stress? Commun. Integr. Biol. 2008, 1, 69-73. [CrossRef]

42. Bashan, Y.; Dubrovsky, J.G. Azospirillum spp. participation in dry matter partitioning in grasses at the whole plant level. Biol. Fertil. Soils 1996, 23, 435-440. [CrossRef]

43. Nouri, E.; Breuillin-Sessoms, F.; Feller, U.; Reinhardt, D. Correction: Phosphorus and nitrogen regulate arbuscular mycorrhizal symbiosis in Petunia hybrida. PLoS ONE 2015, 10, e0127472. [CrossRef] [PubMed]

44. Abayomi, Y.A.; Ajibade, T.V.; Sammuel, O.F.; Saadudeen, B.F. Growth and yield responses of cowpea (Vigna unguiculata (L.) Walp) genotypes to nitrogen fertilizer (NPK) application in the Southern Guinea Savanna zone of Nigeria. Asian J. Plant Sci. 2008, 7, 170-176. [CrossRef]

45. Valverde, A.; Burgos, A.; Fiscella, T.; Rivas, R.; Velázquez, E.; Rodríguez-Barrueco, C.; Cervantes, E.; Chamber, M.; Igual, J.M. Differential effects of coinoculations with Pseudomonas jessenii PS06 (a phosphate-solubilizing bacterium) and Mesorhizobium ciceri C-2/2 strains on the growth and seed yield of chickpea under greenhouse and field conditions. Plant Soil 2006, 287, 43-50. [CrossRef]

46. Parra-Cota, F.I.; Peña-Cabriales, J.J.; De Los Santos-villalobos, S.; Martínez-Gallardo, N.A.; Délano-Frier, J.P. Burkholderia ambifaria and B. caribensis promote growth and increase yield in grain amaranth (Amaranthus cruentus and A. hypochondriacus) by improving plant nitrogen uptake. PLoS ONE 2014, 9, e88094. [CrossRef] [PubMed]

(C) 2019 by the authors. Licensee MDPI, Basel, Switzerland. This article is an open access article distributed under the terms and conditions of the Creative Commons Attribution (CC BY) license (http:/ / creativecommons.org/licenses/by/4.0/). 